\title{
Isolation and Control of Fungal Pathogens Associated with Spoiled Carica papaya (L.) Fruit in Mubi Main Market using Aqueous Leaf Extract of Sida acuta. (L.)
}

\author{
C. S. Yusuf, T. D. Tizhe, U. James, N. N. Zakawa, and P. J. Wazamda
}

\section{ABSTRACT}

The fruit of Carica papaya (pawpaw) is an important crop widely grown around the world. Isolation and control of fungi associated with spoiled pawpaw in the Mubi main market were carried out. A total of twenty (20) pawpaw fruits were collected from four locations, the isolation and characterization were done using standard procedure. The result revealed that four fungi cause pawpaw spoilage in the study area (Aspergillus niger, Penicillium expansum, Mucos spp and Rhizopus stolonifer) and were confirmed through a pathogenicity test. Location 3 of the main market showed the highest disease incidence of $50 \%$; location 2 the least with $20 \%$. The efficacy of leaf extract of $S$. acuta was tested for antifungal activities against the four isolates and was positive as the zone of inhibition by the extract increases with an increase in concentration. It can be concluded that $A$. niger, $P$. expansum, Mucos spp and $R$. stolonifer were pathogens responsible for $C$. papaya fruit rot in Mubi main market. $S$. acuta leaf extract was able to restrain the growth of the pathogens. Further research should be carried out to determine the phytochemical present in the leaf extract of $S$. acuta and also to identify the active components in the plants.

Keywords: Inhibition, pawpaw, pennicillium, leaf, growth, pathogen.
Published Online: August 29, 2021

ISSN: 2684-5199

DOI: $10.24018 /$ ejbio.2021.2.4.253

C. S. Yusuf *

Department of Botany, Adamawa State University, Mubi, Nigeria.

(e-mail: baldeino67@gmail.com)

T. D. Tizhe

Department of Botany, Adamawa State University, Mubi, Nigeria.

(e-mail: taritizhe@yahoo.com)

U. James

Department of Botany, Adamawa State University, Mubi, Nigeria.

(e-mail: ussarajames@yahoo.com)

N. N. Zakawa

Department of Botany, Adamawa State University, Mubi, Nigeria.

(e-mail: nzakawa ${ }^{@}$ gmail.com)

P. J. Wazamda

Department of Botany, Adamawa State

University, Mubi, Nigeria.

*Corresponding Author

\section{INTRODUCTION}

Various factors are responsible for changes in which food becomes less palatable or even toxic to consumers these changes may be accompanied by alterations in taste, smell, appearance or texture. Numerous microbial defects of crops are characterized by the types of microorganisms responsible for their deterioration [1]. Fruits are vital sources of nutrients to human beings and provide the body with the necessary vitamins, fats, minerals, and oil for growth and development. Fruits have serious challenges which include abiotic and biotic such as changes in climatic conditions, pests and microbial attacks. These could be due to high sugar levels, nutrient elements, low $\mathrm{pH}$ and moisture contents are associated with a greater predisposition to microbial spoilage. The incidence of fungal spoilage of fruits is a source of potential health hazard to man and animals. Fungi produce mycotoxins which are capable of producing aflatoxin in man, following ingestion or inhalation [2]. Fruits are injured in the process of transporting from farm to market which predisposes them to infection. The postharvest losses and decay of fruits can be traced to infections that occur either between flowering and fruit maturity and subsequent handling and storage activities. They are usually displayed on benches and in baskets for customers in the open markets until sold, thereby exposing them to further microbial infection besides those associated with these whole fruit surfaces and those from adjacent infected fruits [3]. Healthy fruits have many microbes on their surfaces but can usually inhibit their growth until after harvest. Ripening weakens cell walls and decreases the amounts of antifungal chemicals in fruits, and physical damage during harvesting causes breaks in outer protective layers of fruits that spoilage organisms can exploit.

Carica papaya (pawpaw) is cultivated for consumption as fresh fruit and use in drinks, jams, jellies, and ice-cream and as dried and crystallized fruit [13]. The ripe papaya fruit is a good source of calcium and an excellent source of vitamins A and C [4]. Sida acuta commonly known as wire-weed [12] is a specie of flowering plant in the mallow family, malvaceae. The use of synthetic fungicide to control fungal infection has side effects on humans and the environment. It's therefore important to explore other means that is ecofriendly and less lethal to man and other organisms. Therefore, the purpose of this study is to isolate and determined the efficacy of Sida acuta fungi associated with spoiled pawpaw sold in Mubi main market. 


\section{MAterials AND Methods}

\section{A. Sample Collection and Isolation of the Fungi}

Infected pawpaw fruits were collected from four points in the Mubi main market. The fruits were collected into a sterile polythene bag and brought to the laboratory for the study. Plates of already prepared Sabouraud Dextrose Agar (SDA) containing Chloramphenicol (30 mg/l) to prevent the growth of bacteria were inoculated aseptically and incubated at room temperature $\left(25-30{ }^{\circ} \mathrm{C}\right)$ for 7 days. After 7 days, the growth of fungal colonies was observed on the agar plates. The same operation was repeated for the healthy ones, which served as controls.

\section{B. Identification of Isolated Fungi}

A small portion of the mycelium from the fungal cultures was removed and placed on the drop of the stain. The mycelium was spread on the slide with the aid of the mounted needle. A cover slip was placed gently on it and excess liquid was wiped by putting the slide between two folds of filter paper and applying a gentle pressure around the cover slip. The slide was then examined under the microscope. The observation was done at low and high power objectives (XI0 and X40) of the binocular compound microscope. Morphological characteristics of the fungi such as type of hyphae, asexual reproductive structure was observed and recorded.

\section{Pathogenicity Test}

Healthy pawpaw was surfaced I sterilized with $1 \%$ Sodium hypochlorite for 2 minutes and washed with 3 changes of distilled water. Three holes were made with a purified wire loop and small portion of the rotted pawpaw were inoculated into the holes. These set up was incubated for 5-7 days at room temperature and replicated thrice. The growth of fungal colonies were observed and the characters compared with the inoculum.

\section{Preparation of leaf extract}

Fresh leaves of Sida acuta were collected and air-dried at room temperature; it was crushed into powdered form. The aqueous extract was obtained by dissolving $100 \mathrm{~g}$ of the dry powdered plant material in distilled water respectively. The mixture was allowed to stand for $72 \mathrm{hrs}$ during which it was intermittently shaken on a shaking orbit machine. Each mixture was filtered separately through a $0.45 \mathrm{pm}$ nylon membrane filter and the extract was evaporated at $40^{\circ} \mathrm{C}$ by a rotary evaporator. The extracts obtained were weighed and the extractive value of each of the solvent was calculated as thus:

$\%$ Extractive value of the solvent $=\frac{\text { weight of extract }}{\text { Weight of Sample }} \times 100$

\section{E. Effect of plant extract on fungal growth in vitro}

The fungicidal activity of the plant extract was determined using agar well diffusion method. The extract was prepared into four different concentrations 50, 100, 200 and $400 \mathrm{mg} / \mathrm{ml}$. The isolated organisms were dropped on the freshly prepared SDA. Four wells were punched on the inoculated SDA plate using a sterile cork borer of $3 \mathrm{~mm}$. The wells were properly labeled according to the different concentrations of the extract prepared. The punctured wells were filled with $0.2 \mathrm{ml}$ of the extract, the plate were then allowed to stay on the laboratory table for one hour for the extract to diffuse into the agar after which they were incubated at $28^{\circ} \mathrm{c}$ for 24 hours. The plates were observed for any evidence of any inhibition which appeared as clear zones that was completely devoid of growth around the wells. The diameter of the clear zones was measured using a transparent ruler calibrated in millimeter $(\mathrm{mm})$.

\section{F. Data Analysis}

The mean values obtained from the microbiological evaluation of pawpaw were analyzed by independent samples $t$-test and to determine any statistically significant difference $(P<0.05)$ by one-way analysis of variance (ANOVA) followed by post hoc DMT test using SPSS 20.00 software (SPSS version 20).

\section{RESULTS}

The occurrence of fungal pathogens at four points in Mubi main market shows the presence of $A$. niger and $R$. stonolifer in all the four locations of the market whereas $P$. expansum and Mucus spp were present in three of the four locations (Table I) respectively. The disease incidence as revealed in location 3 has the highest with $50 \%$ and location 2 was the lowest with $20 \%$ respectively.

\begin{tabular}{cccccc}
\multicolumn{5}{c}{ TABLE I: OCCURRENCE AND INCIDENCE OF FUNGI } \\
\hline \multirow{5}{*}{ Site } & A. niger & $\begin{array}{c}\text { P. } \\
\text { expansum }\end{array}$ & $\begin{array}{c}\text { R. } \\
\text { stolonifer }\end{array}$ & $\begin{array}{c}\text { Mucus } \\
\text { sp }\end{array}$ & $\begin{array}{c}\text { Incidence } \\
(\%)\end{array}$ \\
\hline 1 & & + & + & + & 30 \\
2 & + & + & + & - & 20 \\
3 & + & - & + & + & 50 \\
4 & + & + & + & + & 35 \\
\hline $\mathrm{KEY}:+=$
\end{tabular}

\section{A. Determination of Pathogenicity}

All the fungal isolates observed were pathogenic, causing spoilage of $C$. papaya (pawpaw). The various disease symptoms caused by each of the isolates showed indistinguishable growth characteristic features to the original diseased samples which cause the rot (Table II).

TABLE II: PATHOGENICITY TEST

\begin{tabular}{ccccc}
\hline & \multicolumn{5}{c}{ Fungal Pathogens } \\
\cline { 2 - 5 } Day & A. niger & P. expansum & Mucus $\mathrm{sp}$. & R. stolonifer \\
\hline 1 & + & - & + & + \\
2 & + & - & + & + \\
3 & + & + & + & + \\
4 & + & + & + & + \\
5 & + & + & + & + \\
\hline
\end{tabular}

Key: $+=$ isolate growth with similar characteristic features to the original diseased samples; - = isolate not able to grow on the sample.

\section{B. Effect of Leaf Extract}

The efficacy of the leaf extract of Sida acuta on the isolated fungi; A. niger, P. expansum, Mucus spp and R. stolonifer shows that the zones of inhibition increase with the increase of concentration. There were significant differences between the control and all the concentrations $(50,100,200$ and $400 \mathrm{mg} / \mathrm{ml}$ ) respectively, the least concentration showed no zones of inhibition (Table III). 
TABLE III: EFFECT OF LEAF EXTRACT OF SIDA ACUTA ON THE ISOLATED FUNGI

\begin{tabular}{|c|c|c|c|c|}
\hline Extract & \multicolumn{4}{|c|}{ Diameter of Zone Of Inhibition (mm) } \\
\hline$(\mathrm{mg} / \mathrm{ml})$ & A. niger & P. expansum & Mucus spp & R. stolonifer \\
\hline 400 & $9.667^{\mathrm{c}}$ & $6.000^{c}$ & $8.333^{\mathrm{c}}$ & $7.667^{\mathrm{c}}$ \\
\hline 200 & $8.000^{\mathrm{c}}$ & $4.667^{\mathrm{cb}}$ & $7.000^{c}$ & $5.333^{\mathrm{b}}$ \\
\hline 100 & $4.333^{\mathrm{b}}$ & $2.333^{\mathrm{b}}$ & $3.000^{\mathrm{b}}$ & $4.667^{\mathrm{b}}$ \\
\hline 50 & $0.00^{\mathrm{a}}$ & $0.000^{\mathrm{a}}$ & $0.000^{\mathrm{a}}$ & $0.000^{\mathrm{a}}$ \\
\hline Control & $13.667^{\mathrm{d}}$ & $11.667^{\mathrm{d}}$ & $12.333^{\mathrm{d}}$ & $12.667^{\mathrm{d}}$ \\
\hline
\end{tabular}

NB: Means with the same superscript along the column are statistically not significantly different at $\mathrm{p}<0.05$.

\section{DISCUSSION}

The results often during this research shows that A. niger, $P$. expansum, Mucus spp and $R$. stolonifer were isolated from rotten pawpaw fruit and were confirmed through pathogenicity test to be the pathogens causing rot in the fruit. This agrees with the works of [5] in which they reported Mucos spp, R. stolonifer and A. niger to be responsible for fruit rot in C. papaya in Mubi. [7] also reported Mucos spp and $A$. niger as the fungal pathogens responsible for fruit rot of $C$. papaya in Girei and Yola south, respectively.

Rot occur in all locations visited in the market, however, location 3 has the highest percentage incidence with $50 \%$. The average rot incidence in the market was $33.8 \%$ this also agrees with the findings of [5] where they reported a percentage incidence of $20.50 \%$ in the Mubi main market. The isolated fungal pathogens were pathogenic, thus responsible for the rot of pawpaw fruits sold in the study area.

The efficacy of leaf extract of $S$. acuta was tested for antifungal activities against the four isolated pathogens from the result obtained, $S$. acuta had some degree of antifungal activities in all the isolated pathogens, this agrees with [8] who reported that leaf extracts of $S$. acuta exhibited activity against bacteria and fungi. The zone of inhibition by the extract increases with an increase in concentration. This is in agreement with the work of [9] where they reported that flavonoids of $S$. acuta have an antifungal effect on Candida albicans. [10] also reported that leaf extract of S. acuta had potential antibacterial and antifungal activities. [11] reported that alkaloids, flavonoids, steroids, terpenoids and phenolic compounds from $S$ acuta leaf extract pose antifungal and antibacterial activities.

\section{CONCLUSION}

From the result of the research, it can be concluded that $A$. niger, $P$. expansum, Mucos spp and $R$. stolonifer are pathogens responsible for $C$. papaya fruit rot in Mubi main market. S. acuta leaf extract was able to inhibit the growth of the pathogen and thus, it can be said to have an antifungal effect. However, S. acuta is available on the site of study and can be used by traders and house whole users to minimize the spoilage of fruit by microbes. Further research should be carried out to determine the phytochemical present in the leaf extract of $S$. acuta and also to identify the active components in the plants.

\section{CONFLICT OF INTEREST}

The authors declared no conflict of interest

\section{ACKNOWLEDGEMENT}

The authors appreciate the effort of all the laboratory staff who assisted in running the laboratory analysis of this study.

\section{REFERENCES}

[1] Akinmusire, O.O. Fungal species Associated with the Spoilage of Some Edible Fruits in Maiduguri Northern Eastern Nigeria. Advances in Environmental Biology, 2011, 5:157-161.

[2] Chaudhary. S.M. and Dhaka, N. Post-harvest diseases of selected fruits in the wholesale market of Dhaka. Bangladesh J. Plant Pathol. 2016, 30(1\&2): 13-16.

[3] Baiyewu, R.A., Amusa, N.A., Ayoola, O.A., Babalola, O.O. Survey of the post-harvest diseases and aflatoxin contamination of marketed pawpaw fruit (Carica papaya) in South-Western Nigeria. African J. Agri. Res, 2007, 2(4): 178-181.

[4] Nakasone, Y. H. and Paul, R. E. Tropical fruits. In: Crop production science in horticulture series, CAB International, Wallingford, 1998, 468.

[5] Magga, B. and Zakawa, N.N. Antifungalactivities of seed extract of mahogany on C. papaya fruit rot in Mubi, Adamawa State.World Journal of Pharmaceutical Research. 2018, 7(14):170-182.

[6] Akintobi, A.O., Okonko, I.O., Agunbiade, S.O., Akano, O.R., Onianwa, O. Isolation and identification of fungi associated with the spoilage of some selected fruits in Ibadan, South-Western Nigeria. Acad. Arena. 2011, 3(11):1-10.

[7] Mairami, M., Fatima, A., Ndana, R., Umar, I. Isolation and identification of fungi species associated with fruit spoilage Bwarri market Abuja, Nigeria. Journal of Advanced Microbiology, 2018, 12:16.

[8] Ekpo, M.A. and Etim, P.C. Antimicrobial activity of ethanolic and aqueous extracts of Sida acuta on micro-organisms from skin infections. Journal of Medicinal Plants, 2009, 3:621-4.

[9] Jindal, A., Kumar, P., Jain, C. Antifungal activity of flavonoids of $S$. acuta Burm against Candida albicans. International Journal of Drug Development and Research, 2012, 4(3):92-96.

[10] Akilandeswari, S., Senthamarai, R., Valarmathi, R., Prema, S. Screening of Gastric Antiulcer Activity of Sida acuta Burm. f. International Journal PharmTech Research, 2010, 2(2):1644-1648.

[11] Edeoga, H.O. Phytochemical constituents of some Nigerian medicinal plants. African Journal of Biotechnology, 2005, 4(7):685-688.

[12] Parson, E. Noxious weeds of Australia (2 ed.). CSIRO Publishing. 2001, 508-509.

[13] Villegas, V.N. (1997). Development of ringspot virus tolerant papaya (Carica papaya L.) varieties. in S. Vijaysegaran, M. Pauziah, M.S. Mohamed and S. Ahmad Tarmizi, eds., Proceedings of the International Conference on Tropical Fruits. Kuala Lumpur, Malaysia. Malaysian Agricultural Research and Development Institute (MARDI), Serdang. 1997, 1: 117-120. 